\title{
PLACE AND ROLE OF THE USA IN THE MODERN WORLD WITH THE EYES OF STUDENTS FROM DIFFERENT COUNTRIES OF THE WORLD
}

\author{
Lymarev A.V., Talanov S.L.
}

Yaroslavl State Pedagogical University,e-mail: talanov_sergei@mail.ru,avlymarev@gmail.com

The place and role of the USA in the modern world is analyzed. The authors conducted a sociological study among students from China, Russia, and the USA. It has been established that a significant part of students recognizes the United States as the leading country in the world, but negatively perceives the foreign policy followed by its Presidents. At the same time, students from China and Russia have the most negative opinion towards the USA. American students perceive positively the influence of their country on current events in the world. It was revealed that regardless of nationality, citizenship, gender characteristics, a significant part of students believe that the highest in the world GDP per capita, the dollar strength and huge military spending provide US with the the leading position in the world. In addition, US students have a clear idea of their country's geopolitical goals. Students from Russia and China have fragmented ideas about the geopolitical goals of the United States in the world. It was also established that most of the respondents, regardless of nationality and citizenship, consider the IS as a threat to the United States. Moreover, students from the Russian Federation are aware that it is prohibited in the territory of the Russian Federation and that the Russian army is fighting with this terrorist organization in Syria. Based on the results of the study, the authors propose activities aimed at enhancing mutually beneficial cooperation between the United States and the Russian Federation.

Keywords: soft power, country image, opinion polls, hegemony of the USA, globalization

According to statistics, the United States has a leading post-industrial economy in the world. Positional experts note that the United States is the absolute leader in the global engineering and chemical industries. $[1,2,3]$ There are a lot of evaluation criteria, starting from the level of GDP, GNI, unemployment, quality and standard of living, prestige of education, the pace of economic growth, up to the military equipment. As several authors rightly point out, most often citizens are better related to a particular country than to the specific political leadership of a particular country. $[4,5$, $6]$ In order to determine the role and place of the United States in the modern world, as well as to analyze the threats and challenges for the United States, we conducted a sociological study (questionnaire) in 2018-2020.

\section{Empirical base of research}

Students were surveyed in:

- Yaroslavl State Pedagogical University named after K.D. Ushinsky (YSPU);

- Yaroslavl State University named after P.G. Demidov (YSU);

Quota sampling. Sample selection $n=800$. Quota variables: gender, age, university.

In addition, a survey of foreign students from the USA and China was conducted.

Content analysis of the following magazines was performed:

- Russian Reporter (issues from 2013 to 2020);

- Around the World (issues from 2013 to 2020),

The content analysis of the weekly newspaper "Version" (issues from 2013 to 2020) has been done.
A content analysis of the blogosphere was conducted as well.

A series of in-depth interviews were done with positional experts (political scientists, politicians, etc.) $\mathrm{n}=10$.

In addition, a series of in-depth interviews with students were followed, $\mathrm{n}=10$.

\section{Research hypotheses}

- A significant portion of students regardless of nationality, citizenship, gender characteristics consider the United States the leading country in the world.

- Students from the USA, China and Russia have completely different perceptions of the role of the USA in the modern world. Absolutely all students from the USA treat their state well, although they note a number of problems that arise in the USA through the fault of the Government. Students from China and Russia have the most negative opinion towards the USA.

- The higher the educational level of the respondents' parents, the better is their attitude towards the USA.

The methodological basis of the study was the scientific works of such authors as P. Bourdieu, W. Lippmann, N. Luman, and Y.A. Levada, E. Noel-Neumann, J. Zaller, J. Habermas, S. Talanov. [7, 8, 9]

Content analysis of magazines: Russian Reporter, Around the World, "Version" newspaper and content analysis of the blogosphere showed that in recent years there has been a lot of negative information about the United States.

A secondary analysis was carried out on the basis of data and publications of the results of studies carried out by the Institute of 
Sociology of the Federal Scientific Research Center for Scientific Research of RAS (Moscow), VTsIOM (Russian Public Opinion Research Center).

\section{Research results and their analysis}

First, we studied what influence the USA has in the world from the point of view of our respondents (Table 1).

Table 1

Attitude to US influence in the world

(in \%, of the number of respondents)

\begin{tabular}{|l|c|c|c|c|c|c|}
\hline \multirow{2}{*}{} & \multicolumn{6}{|c|}{ Students } \\
\cline { 2 - 7 } & \multicolumn{2}{|c|}{ China } & \multicolumn{2}{c|}{ Russia } & \multicolumn{2}{c|}{ The USA } \\
\cline { 2 - 7 } & $\mathrm{M}$ & $\mathrm{F}$ & $\mathrm{M}$ & $\mathrm{F}$ & $\mathrm{M}$ & $\mathrm{F}$ \\
\hline Good & 21 & 17 & 31 & 40 & 86 & 81 \\
\hline Indifferent & 8 & 9 & 12 & 7 & 6 & 9 \\
\hline Bad & 71 & 74 & 57 & 53 & 8 & 10 \\
\hline
\end{tabular}

It was found that only students from the United States positively evaluate US activities in the world. Students from China and Russia assess the activities of the United States on events in the world mostly negatively. Moreover, students from China to have worse attitude towards the United States than students from the Russian Federation.

Further, it was important for us as researchers to find out what factors determine US dominance in the world (Table 2).

As can be seen from the responses of the respondents, regardless of nationality, citizen- ship, gender characteristics, a significant part of students believe that the highest per capita GDP in the world, the US Dollar and huge military spending provide the leading US position in the world.

It is interesting that young men from China and the Russian Federation believe that their intelligence services provide leadership in the world for the United States. Students from the United States did not focus at all on this circumstance.

Given that after the collapse of the USSR, the world became unipolar, as part of the study, we made an attempt to study the geopolitical goals of the United States from the point of view of our respondents (Table 3 ).

From the responses of the respondents, it is clear that US students clearly understand their country's geopolitical goals.

Students from the Russian Federation and China were able to identify only one of the five geopolitical goals of the United States and then, only young men did that.

According to VTsIOM, Levada Center, Public Opinion Fund and other sociological services, it has been established that people in the world have an ambiguous attitude on the part of people and politicians from different countries. Opinion polls more often show a negative attitude towards the United States from an increasing number of people. That is why, we analyzed the reason for the negative attitude towards the United States from many people, from the point of view of our respondents (Table 4).

Table 2

Distribution of answers to the question: «What determines the influence of the USA in the world?»* (in $\%$, of the number of respondents)

\begin{tabular}{|l|c|c|c|c|c|c|}
\hline \multirow{2}{*}{} & \multicolumn{5}{|c|}{ Students } \\
\cline { 2 - 6 } & \multicolumn{2}{|c|}{ China } & \multicolumn{2}{c|}{ Russia } & \multicolumn{2}{|c|}{ The USA } \\
\cline { 2 - 6 } & $\mathrm{M}$ & $\mathrm{F}$ & $\mathrm{M}$ & $\mathrm{F}$ & $\mathrm{M}$ & $\mathrm{F}$ \\
\hline The world's highest GDP per capita & 100 & 87 & 100 & 88 & 100 & 100 \\
\hline US Dollar as world currency & 98 & 89 & 100 & 90 & 100 & 100 \\
\hline The US economy holds a leading position in the world & 86 & 84 & 43 & 13 & 100 & 100 \\
\hline The strongest army in the world (army financing) & 85 & 86 & 88 & 85 & 100 & 100 \\
\hline Us intelligence (using its covert operations) allows US to dominate the world & 87 & 12 & 83 & 15 & 21 & 14 \\
\hline Provide financial support to foreign countries & 56 & 32 & 13 & 10 & 87 & 84 \\
\hline Universities are the best in the world & 42 & 45 & 56 & 87 & 78 & 82 \\
\hline The USA is No. 1 in the world in oil and natural gas production & 37 & 14 & 22 & 16 & 63 & 53 \\
\hline The rapid development of innovation & 34 & 32 & 20 & 15 & 67 & 68 \\
\hline Law supremacy & 13 & 8 & 8 & 7 & 86 & 87 \\
\hline Active role of defender of the free world & 12 & 7 & 7 & 6 & 79 & 82 \\
\hline Other & 5 & 5 & 5 & 5 & 5 & 6 \\
\hline
\end{tabular}

Note: $*$ The total percentage in the vertical might be more than 100 , because respondents could indicate several answers. 
Distribution of answers to the question: «US geopolitical goals? *

Table 3

(in \%, of the number of respondents)

\begin{tabular}{|l|c|c|c|c|c|c|}
\hline \multirow{2}{*}{} & \multicolumn{7}{|c|}{ Students } \\
\cline { 2 - 8 } & \multicolumn{2}{|c|}{ China } & \multicolumn{2}{|c|}{ Russia } & \multicolumn{2}{c|}{ The USA } \\
\cline { 2 - 8 } & $\mathrm{M}$ & $\mathrm{F}$ & $\mathrm{M}$ & $\mathrm{F}$ & $\mathrm{M}$ & $\mathrm{F}$ \\
\hline $\begin{array}{l}\text { Complete domination of the oceans and control over the interna- } \\
\text { tional trading system }\end{array}$ & 100 & 67 & 100 & 87 & 99 & 98 \\
\hline Depriving any country of the ability to resist US global superiority & 36 & 11 & 34 & 17 & 95 & 93 \\
\hline $\begin{array}{l}\text { Full control over maritime access to the USA and prevention of any } \\
\text { possibility of invasion from the sea }\end{array}$ & 34 & 36 & 28 & 24 & 99 & 99 \\
\hline Elimination of any US threat from a Western hemisphere state & 31 & 35 & 34 & 21 & 99 & 99 \\
\hline Total US dominance in North America & 24 & 26 & 43 & 12 & 100 & 100 \\
\hline Other & 5 & 6 & 5 & 5 & 5 & 5 \\
\hline
\end{tabular}

Note: $*$ The total percentage in the vertical might be more than 100 , because respondents could indicate several answers.

Table 4

Distribution of answers to the question: «Why do you think people are negative towards the USA?»* (in $\%$, of the number of respondents)

\begin{tabular}{|l|c|c|c|c|c|c|}
\hline \multirow{2}{*}{} & \multicolumn{7}{|c|}{ Students } \\
\cline { 2 - 8 } & \multicolumn{2}{|c|}{ China } & \multicolumn{2}{c|}{ Russia } & \multicolumn{2}{c|}{ The USA } \\
\cline { 2 - 8 } & $\mathrm{M}$ & $\mathrm{F}$ & $\mathrm{M}$ & $\mathrm{F}$ & $\mathrm{M}$ & $\mathrm{F}$ \\
\hline US restricts the free trade & 100 & 67 & 100 & 87 & 9 & 8 \\
\hline US intervenes in internal affairs of other countries & 87 & 82 & 84 & 80 & - & - \\
\hline $\begin{array}{l}\text { Citizens of different countries do not treat US citizens badly, but } \\
\text { their government }\end{array}$ & 51 & 46 & 43 & 35 & 62 & 56 \\
\hline Because of the media, which creates the image of the enemy & 34 & 33 & 47 & 44 & 66 & 62 \\
\hline Other & 5 & 5 & 6 & 5 & 5 & 5 \\
\hline
\end{tabular}

Note: $*$ The total percentage in the vertical might be more than 100 , because respondents could indicate several answers.

As can be seen from the survey, students from China and the Russian Federation, regardless of gender characteristics, believe that the United States intervenes in the internal affairs of other countries and restrict free trade.

Students had the opportunity to clarify their answers. So, students from the United States believe that the media creates the image of the enemy. And despite this circumstance, most people still do not treat the United States and its citizens badly, but the actions of its politicians.

Next, we studied why a certain part of the population has a positive attitude towards the USA (Table 5).

As can be seen from the answers, more than half of the students from China and the Russian Federation associate the people's good attitude towards the United States with the quality of propaganda of the American media.

Interviewees had the opportunity to clarify their answers. The questionnaire had open questions for this purpose. Students from Russia mostly indicated that they are negative towards the United States. Since the United States does not protect the economic situation of other countries, it intervenes in the affairs of other countries. Politicians in the United States come up with sanctions against the Russian Federation for purpose, in other words, they are engaged in protectionism. Since the sanctions are far-fetched and impose against Russia in order to eliminate Russian manufacturers from the world market. As a result, manufacturing facilities are developing in the United States, and not in the Russian Federation. As a result, the quality and standard of living in Russia is falling.

Here we see that the ongoing decrease of real incomes of the population in the Russian Federation, lasting since 2014 till today, respondents from Russia connect with a hostile US policy. 
The opinion of students from China is interesting, which, alike students from the Russian Federation, are negatively related to the United States. Students noted that politicians from the United States are constantly trying to exert economic pressure on Chinese manufacturers. Students believe that the United States through sanctions restricts free trade in the world. At the same time, China is blaming it all the time.

Students from the United States believe that their country is the engine of the global economy. And citizens of other countries are hostile to the United States, as they envy the way life in America flourishes. At the same time, students from the United States believe that due to Chinese policies in the United States, the trade deficit is growing, which costs their country $1 \%$ of GDP growth. According to respondents, citizens from China are systematically engaged in industrial espionage and wage cyber war against their country. In addition, China is building up the power of the armed forces. It is interesting, that a significant portion of US students do not consider the Rus- sian Federation as an enemy. Perhaps this is due to the impact of "soft power", it is difficult to negatively relate to the country in which you yourself voluntarily have chosen to study. We observed the same situation when interviewing students from China, who also indicated during the survey that they did not consider the Russian Federation as an enemy.

Here we see that US students believe that China poses a threat to the US economy and national security.

The discussion of students about the United States is certainly of particular interest to us as researchers, but it was important to understand how competent our respondents are to American political issues, how often they watch political news, whether they analyze the activity of electoral behavior in the United States, where do they get information about the United States?

For this reason, further we made an attempt to find out how strong is the interest of our respondents in American politics in general (Table 6).

Table 5

The answer to the question: «Why do you think people are positive towards the United States?»* (in \%, of the number of respondents)

\begin{tabular}{|c|c|c|c|c|c|c|}
\hline & \multicolumn{6}{|c|}{ Students } \\
\hline & \multicolumn{2}{|c|}{ China } & \multicolumn{2}{|c|}{ Russia } & \multicolumn{2}{|c|}{ The USA } \\
\hline & M & $\mathrm{F}$ & M & $\mathrm{F}$ & $\mathrm{M}$ & $\mathrm{F}$ \\
\hline $\begin{array}{l}\text { The propaganda of US representatives in different countries through } \\
\text { the media creates the ideal image for the state and its politicians. }\end{array}$ & 66 & 64 & 62 & 63 & - & - \\
\hline People can find information on the Internet about real-world events. & 17 & 16 & 13 & 10 & 23 & 16 \\
\hline $\begin{array}{l}\text { People have repeatedly talked with citizens from the United States } \\
\text { and have a real idea of them. }\end{array}$ & 15 & 12 & 14 & 11 & 65 & 61 \\
\hline Some people were in the USA and have a real idea of the country. & 14 & 13 & 28 & 26 & 78 & 72 \\
\hline $\begin{array}{l}\text { US model of social and economic development for the rest of the } \\
\text { world }\end{array}$ & 12 & 13 & 12 & 14 & 84 & 81 \\
\hline Other & 5 & 5 & 6 & 5 & 5 & 6 \\
\hline
\end{tabular}

Note: $*$ The total percentage in the vertical might be more than 100 , because respondents could indicate several answers.

Students' interest in US Politics in general

Table 6 (in $\%$, of the number of respondents)

\begin{tabular}{|l|c|c|c|c|c|c|}
\hline \multirow{2}{*}{} & \multicolumn{9}{|c|}{ Students } \\
\cline { 2 - 7 } & \multicolumn{2}{|c|}{ China } & \multicolumn{2}{c|}{ Russia } & \multicolumn{2}{c|}{ The USA } \\
\cline { 2 - 7 } & $\mathrm{M}$ & $\mathrm{F}$ & $\mathrm{M}$ & $\mathrm{F}$ & $\mathrm{M}$ & $\mathrm{F}$ \\
\hline significant interest or attention & 32 & - & 24 & - & 75 & 76 \\
\hline some interest or attention & 39 & 36 & 35 & 33 & 11 & 12 \\
\hline little interest or attention & 24 & 59 & 36 & 62 & 9 & 7 \\
\hline I do not know & 5 & 5 & 5 & 5 & 5 & 5 \\
\hline
\end{tabular}


As can be seen from the answers, a significant interest in US politics among students from America, which in principle is very logical. Interestingly, students from China and the Russian Federation have a significant interest in US politics only for a small part of students. Moreover, for ladies, politics in the United States is generally not of significant interest and attention.

Next, we analyzed if students had an interest in national election campaigns in the United States (Table 7).

The responses indicated that respondents from China and the Russian are interested in the election campaign in the United States higher than in the political process in the United States.

Obviously, a lot depends on who comes to power in the country with the strongest economy and army in the world. Therefore, students are very carefully interested in election campaigns in the United States.

Then we studied whether students are striving to obtain information about what is happening in political life in the United States and is this information of interest to them? (Table 8).

From the answers it is clear that students from China and the Russian Federation do not show significant interest in the events taking place in everyday political life in the United States. Students had the opportunity to clarify their answers. So, more than half of the students from the Russian Federation explained that they receive information about political life in the United States from programs on Russian television. One-third of students indicated that they listen to programs on "Moscow Echo" radio station and watch programs of A. Navalny and L. Sobol. As we see, the sources for obtaining information about political life in the USA are different for students, which is good itself, since any civilized person needs to critically evaluate any information received.

Next, we studied who can currently be considered as the enemy for the United States from the point of view of respondents (Table 9).

It is interesting, that students from China believe that it is not their country posing a threat to the United States to a greater extent, but the Russian Federation. And students from the Russian Federation believe that China is a threat to the United States. In turn, students from the United States believe that there are many threats. The United States, in their view, is threated by China, Saudi Arabia and Pakistan, and a number of other countries.

Students had the opportunity to clarify their answers. So, students from the United States indicated that Saudi Arabia poses a threat to America and the whole world, as it finances terrorists. China poses a threat as it builds up the navy and imposes sanctions against the US.

Next, we analyzed which terrorist groups (organizations) threaten the United States from the point of view of our respondents (Table 10).

Table 7

Students' interest in national election campaigns in the USA

(in $\%$, of the number of respondents)

\begin{tabular}{|l|c|c|c|c|c|c|}
\hline \multirow{2}{*}{} & \multicolumn{4}{c|}{ Students } \\
\cline { 2 - 7 } & \multicolumn{2}{|c|}{ China } & \multicolumn{2}{c|}{ Russia } & \multicolumn{2}{c|}{ The USA } \\
\cline { 2 - 7 } & $\mathrm{M}$ & $\mathrm{F}$ & $\mathrm{M}$ & $\mathrm{F}$ & $\mathrm{M}$ & $\mathrm{F}$ \\
\hline significant interest or attention & 44 & 12 & 35 & 15 & 77 & 78 \\
\hline some interest or attention & 31 & 32 & 24 & 20 & 11 & 13 \\
\hline little interest or attention & 20 & 51 & 36 & 60 & 12 & 9 \\
\hline I do not know & 5 & 5 & 5 & 5 & - & - \\
\hline
\end{tabular}

Information on what is happening in the political life in the USA

Table 8 (in $\%$, of the number of respondents)

\begin{tabular}{|l|c|c|c|c|c|c|}
\hline \multirow{2}{*}{} & \multicolumn{9}{|c|}{ Students } \\
\cline { 2 - 7 } & \multicolumn{2}{|c|}{ China } & \multicolumn{2}{c|}{ Russia } & \multicolumn{2}{c|}{ The USA } \\
\cline { 2 - 7 } & M & F & M & F & M & F \\
\hline significant interest or attention & 30 & - & 23 & - & 75 & 76 \\
\hline some interest or attention & 39 & 34 & 36 & 33 & 11 & 12 \\
\hline little interest or attention & 26 & 59 & 36 & 62 & 14 & 12 \\
\hline I do not know & 5 & 7 & 5 & 5 & - & - \\
\hline
\end{tabular}


Table 9

Distribution of answers to the question: «Who do you think is currently the enemy for the United States?»* (in \%, of the number of respondents)

\begin{tabular}{|l|c|c|c|c|c|c|}
\hline \multirow{2}{*}{} & \multicolumn{9}{|c|}{ Students } \\
\cline { 2 - 7 } & \multicolumn{2}{|c|}{ China } & \multicolumn{2}{c|}{ Russia } & \multicolumn{2}{c|}{ The USA } \\
\cline { 2 - 7 } & $\mathrm{M}$ & $\mathrm{F}$ & $\mathrm{M}$ & $\mathrm{F}$ & $\mathrm{M}$ & $\mathrm{F}$ \\
\hline Russia & 67 & 63 & 23 & 18 & 54 & 51 \\
\hline North Korea & 54 & 46 & 32 & 12 & 58 & 54 \\
\hline Saudi Arabia & 32 & 21 & 19 & 11 & 60 & 57 \\
\hline Iran & 31 & 17 & 37 & 32 & 56 & 55 \\
\hline China & 23 & 18 & 67 & 66 & 78 & 73 \\
\hline Pakistan & 14 & 7 & 7 & - & 65 & 62 \\
\hline Afghanistan & 13 & 7 & 6 & 7 & 32 & 23 \\
\hline Venezuela & 12 & 7 & 13 & 10 & 47 & 45 \\
\hline Cuba & 6 & 6 & 5 & - & 12 & 10 \\
\hline Syria & 6 & - & 12 & - & 43 & 41 \\
\hline Iraq & 5 & - & - & - & 32 & 29 \\
\hline Other countries & 5 & 5 & 5 & 5 & 6 & 5 \\
\hline
\end{tabular}

Note: $*$ The total percentage in the vertical might be more than 100 , because respondents could indicate several answers.

Distribution of answers to the question: «Which groups (organizations)

Table 10 in your opinion are currently the enemy for the United States?»*

(in \%, of the number of respondents)

\begin{tabular}{|l|c|c|c|c|c|c|}
\hline \multirow{2}{*}{} & \multicolumn{5}{c|}{ Students } \\
\cline { 2 - 7 } & \multicolumn{2}{|c|}{ China } & \multicolumn{2}{c|}{ Russia } & \multicolumn{2}{c|}{ The USA } \\
\cline { 2 - 7 } & $\mathrm{M}$ & $\mathrm{F}$ & $\mathrm{M}$ & $\mathrm{F}$ & $\mathrm{M}$ & $\mathrm{F}$ \\
\hline IS (banned in the Russian Federation) & 89 & 45 & 100 & 76 & 87 & 84 \\
\hline Hezbollah & 54 & 21 & 64 & 16 & 75 & 63 \\
\hline Al qaeda (banned in the Russian Federation) & 51 & 21 & 52 & 17 & 100 & 100 \\
\hline Haqqani Network (banned in the Russian Federation) & 32 & 7 & 17 & - & 76 & 64 \\
\hline Quds Forces & 15 & - & 35 & - & 43 & 36 \\
\hline Other & 5 & 5 & 5 & 5 & 5 & 6 \\
\hline
\end{tabular}

Note: * The total percentage in the vertical might be more than 100 , because respondents could indicate several answers.

As can be seen from the answers, most of the respondents, regardless of nationality and citizenship, consider the IS terrorist organization as a threat to the USA. Moreover, students from the Russian Federation are aware that it is prohibited in the territory of the Russian Federation and that the Russian army is fighting with this terrorist organization in Syria.

This question was open in the questionnaire, so respondents had to write down the name of the terrorist organization in the line. The table shows that the respondents know the terrorist groups, which are are enemies of the
United States. A significant part of the respondents, regardless of citizenship (nationality), gender, and direction of study, correctly indicated that terrorist groups of radical Islamists pose as a threat to the United States. Students from the United States not only listed the name of the groups, but also correctly indicated their affiliation. So, all respondents from America noted that Hezbollah is a paramilitary Lebanese Shiite organization and political party.

Next, we attempted to find out why China poses a threat to the United States and what exactly is this threat? (table 11). 
Table 11

Distribution of answers to the question: «Why is China a threat to the United States?»* (in $\%$, of the number of respondents)

\begin{tabular}{|l|c|c|c|c|c|c|}
\hline \multirow{2}{*}{} & \multicolumn{7}{|c|}{ Students } \\
\cline { 2 - 8 } & \multicolumn{2}{|c|}{ China } & \multicolumn{2}{|c|}{ Russia } & \multicolumn{2}{c|}{ The USA } \\
\cline { 2 - 8 } & $\mathrm{M}$ & $\mathrm{F}$ & $\mathrm{M}$ & $\mathrm{F}$ & $\mathrm{M}$ & $\mathrm{F}$ \\
\hline Conducts industrial espionage and cyber war against the USA & 13 & 8 & 87 & 54 & 85 & 83 \\
\hline Making systematic attempts to destroy US industrial base & 12 & 11 & 78 & 63 & 87 & 72 \\
\hline $\begin{array}{l}\text { Large-scale manipulations of China with its own currency to } \\
\text { stimulate exports }\end{array}$ & 10 & 7 & 71 & 57 & 100 & 100 \\
\hline Other & 5 & 5 & 5 & 5 & 5 & 5 \\
\hline
\end{tabular}

Note: * The total percentage in the vertical might be more than 100 , because respondents could indicate several answers.

As can be seen from the survey, US students see China as a threat to their economy. Russian students also see China as a threat to US industry and economy.

Students had the opportunity to clarify their answers. So, students from the United States noted that the value of the renminbi is underestimated by $50 \%$ compared to its real value. As a result, China can sell its goods half the price of American goods. US companies are not competitive. Because of this, there is an increase in unemployment in the United States.

As part of the study, we conducted a series of in-depth interviews with students from different countries.

Below we provide some of their statements.

Christina

"China is hostile to my country. In particular, China adopted the doctrine of Integrated Network Electronic Warfare. China is destroying my country's industry, stealing military and civilian technologies. US unemployment is increasing because of China".

Michael

"Unemployment is growing, in the USA. The media in my country associates this with Chinese politics. I constantly analyze information in the field of world economy and politics. My concern is the fact that the Chinese economy is growing at $10 \%$, and the American economy is growing at an average of $2 \%$. The US has a huge trade deficit with China. But I'm sure that the future is all the same for the USA. America has a high proportion of people with a high level of education and competitive skills".

William

"For any country, the main thing is to stimulate the economy, create new jobs, increase labor productivity, improve the quality and standard of living of people. Unfortunately, there is a decrease in the living standards of a number of states. China is usually blamed for this, but I believe that the problem is not only related to Chinese policy, but also to problems in American domestic politics. In the USA, corporate tax is high (higher only in Japan) as a result, businesses are trying to save on taxes by transferring their enterprises abroad. It is necessary to reduce tax rates in order to stop the flight of capital abroad. I believe that it was important to reduce the tax rate on capital gains and dividends, this was stimulating the creation of new jobs and attracting investment".

Here we can notice that US students see a threat from China side.

The opinion of Russian students is also interesting.

Egor

"The USA pursues an aggressive policy in the world. They have the largest government debt when compared to GDP. The mass of internal unsolved problems, in particular the problem of crime, drug addiction, unemployment. Every 7 US citizens receives food stamps. Instead of solving the problems of their country, the US government is constantly looking for a reason somewhere to start another war or make a color revolution. The US State Department finances liberals in the Russian Federation. Then, the politicians from the USA are surprised why no one or a few people like Americans in the world".

As you can see, a number of Russian students very negatively assess the role and place of the United States in the modern world. As part of the interview, we found out that Egor has no acquaintances and friends from the United States and he never was in the USA. In addition, Egor is a member of the Young Guard (youth organization) of United Russia. Regardless of his socio-political views, it can be stated that for most of the Russian students, the United States is still a hostile country. 
As part of our research, we conducted a series of in-depth interviews with positional experts. Below we give some of their statements.

Positional expert 1. "The US will continue to dominate the world. Politicians in the United States have consistently implemented the Truman Doctrine, the Eisenhower Doctrine, and the Kennedy Doctrine. US politicians adequately respond to modern challenges in the world. Despite the periodic increase in oil and gas prices in the world, the United States due to the available reserves of natural gas is able to fully satisfy America's energy needs. Suffice it to recall the largest natural gas field Marcellus Sheil. In addition, shale gas is being actively developed in the United States. All this allows the United States to ensure energy security. And this, in turn, ensures the ongoing development of the economy".

Positional expert 2. "According to forecasts, China will overtake the United States by 2027 and become the largest economy in the world. But this is according to analysts. The reality today is that in the United States, despite the global crisis, there is an increase in economic and military power. The United States skillfully creates economic, military, and political alliances. It provides financial support to foreign countries and expands its influence through soft power. Every year, leading scientists of the world strive to come to the United States, therefore America has at its disposal the best intellectual world resources. The concern of the USA is caused by the actions of Saudi Arabia to finance global terrorism. In the economic field, China is a major irritant".

Positional expert 3. "The United States secures its influence through the power of covert operations. America has powerful intelligence services that provide a unseen impact on world events. The majority of the population of the Russian Federation has a negative attitude towards the United States, since a negative image is created in the materials of permanent columnists, in news articles, reports, newspaper and magazine articles about the USA".

As we can see, positional experts believe that the United States will dominate the world for a long time and currently China is the only real rival.

\section{Conclusion}

Given the ever-growing role of the United States in the world, it is important to interact constructively with its political elite.

For this reason, we believe that it is necessary to:

- the media more objectively and constructively cover ongoing processes in the United States;

- develop humanitarian international cooperation;

- periodically hold scientific and practical conferences on intercultural interaction;

- to work more actively with various target groups in the USA;

- to systematically invite famous teachers and politicians from the USA to conduct open lectures at universities.

There are many problems in the world that can only be solved with the constructive interaction of the USA and the Russian Federation.

\section{References}

1. Gallarotti G. Cosmopolitan Power in International Relations: A Synthesis of Realism, Neoliberalism, and Constructivism. N.Y.: Cambridge University Press, 2010. 307 p.

2. Nye J.S. The Paradox of American Power: Why the World's Only Superpower Can't Go It Alone, Oxford University Press, 2002. $147 \mathrm{p}$.

3. Nye J.S. The Paradox of American Power: Why the World's Only Superpower Can't Go It Alone, Oxford University Press, 2002. $147 \mathrm{p}$.

4. Nazarenko A.V. New reality - new caring, new political alliances and new archaic // Social and Humanitarian Knowledge. 2018. No 4. P. 192-203.

5. Oganisyan Yu.S. International Security: Network Context // Social and Humanitarian Knowledge. 2018. No 5. P. 117-127.

6. Talanov N.S. Present and future in the views of Yaroslavl schools' students // Start in science. 2017. No 1. P. 67-69.

7. Baburkin S.A. Espionage against the United States in the estimates of the US counterintelligence // Yaroslavl Pedagogical Herald. 2010. Vol. 1. No 4. P. 132-138.

8. Lymarev A.V. Human Intelligence (HUMINT) fighting international terrorism: the experience of the USA // Yaroslavl Pedagogical Herald. 2011. Vol. 1. No 4. P. 160-163.

9. Talanov S.L. Socialization of youth and the prospects for the development of higher education // Alma mater (Higher School Herald). 2010. No 6. P. 34-36. 